\title{
IMPLEMENTASI MODEL KOOPERATIF TIPE JIGSAW DALAM MENINGKATKAN HASIL BELAJAR SISWA TEMA GLOBALISASI SUB TEMA MASYARAKAT ASEAN BEBAS NARKOBA KELAS VI SD 040462 KABANJAHE TAHUN PELAJARAN 2019/2020
}

\author{
Pelista Br Karo Sekali ${ }^{1)}$, Jainab ${ }^{2)}$ \\ ${ }^{122)}$ Dosen FKIP PGSD Universitas Quality \\ Email : pelistakarosekali@yahoo.co.id
}

\begin{abstract}
Penelitian tindakan kelas ini dilaksanakan menerapkan Model Pembelajaran Tipe Jigsaw Tema Globalisasi Sub Masyarakat Asean Bebas Narkoba kelas VI SD 040462 Kabanjahe tahun pelajaran 2019/2020. Tujuan penelitian ini adalah untuk mengetahui Pelaksanaan pembelajaran, mengetahui Ketuntasan Hasil belajar dan untuk mengetahui peningkatan hasil belajar siswa. Subjek penelitan ini adalah kelas VI berjumlah 31 orang dan objek penelitian implementasi Model pembelajaran Tipe Jigsaw. Instrumen yang digunakan adalah lembar observasi dan tes essay.

Berdasarkan hasil penelitian Siklus I diperoleh Pelaksanaan Pembelajaran aktivitas guru $60 \%$ kreteria cukup dan siklus II diperoleh $80 \%$ kreteria baik, aktivitas siswa siklus I diperoleh nilai 66 kreteria cukup dan hasil penelitian siklus II nilai 85 kreteria baik. Ketuntasan belajar siswa siklus I 68\% atau 21 orang dari 30 siswa dalam satu kelas. Siklus II ketuntasan belajar siswa meningkat menjadi $90 \%$ atau 28 orang dan peningkatan mencapai $5 \%$ mengimplementasikan Model Pembelajaran Tipe Jigsaw Tema Globalisasi sub Masyarakat Asean Bebas Narkoba Kelas VI SD 040462 Kabanjahe tahun pelajaran $2019 / 2020$.
\end{abstract}

\section{Kata Kunci : Model Pembelajaran Tipe Jigsaw, Pelaksanaan Pembelajaran, Hasil Belajar}

\begin{abstract}
This class action research was carried out applying the Jigsaw Type Learning Model on the Globalization Theme of the Asean Free Narcotics Sub-Class VI Elementary School 040462 Kabanjahe in the academic year 2019/2020. The purpose of this study was to determine the implementation of learning, know the completeness of learning outcomes and to find out the improvement of student learning outcomes. The subjects of this research were class VI totaling 31 people and the object of research was the implementation of the Jigsaw Type learning model. The instruments used were observation sheets and essay tests.

Based on the results of the Cycle I research, the implementation of learning activities of teachers is $60 \%$ enough criteria and the second cycle is $80 \%$ good criteria, the activity of the cycle I students is 66 grades enough and the results of the second cycle research results 85 good criteria. Mastery learning students cycle I $68 \%$ or 21 people from 30 students in one class. Cycle II completeness of student learning increased to $90 \%$ or 28 people and an
\end{abstract}


increase of up to 5\% to implement the Jigsaw Type Learning Model Theme of Globalization of the Asean Free Narcotics Community Class VI Elementary School 040462 Kabanjahe in the academic year 2019/2020.

\section{Keywords: Learning Model Type Jigsaw, Learning Implementation, Learning Outcomes}

\section{PENDAHULUAN}

Pembangunan nasional dalam bidang pendidikan adalah upaya mencerdaskan kehidupan bangsa dan meningkatkan kualitas manusia Indonesia yang beriman, bertakwa, dan berakhlak mulia serta menguasai ilmu pengetahuan, teknologi, dan seni dalam mewujudkan masyarakat yang maju, adil, makmur, dan beradap berdasarkan Pancasila dan Undang-Undang Dasar Negara Republik Indosesia Tahun 1945. Untuk menjamin peningkatan mutu dan relevansi pendidikan yang mampu menghadapi tantangan sesuai dengan tuntutan perubahan kehidupan nasional dan global, perlu dilakukan peningkatan kualitas guru secara terencana, terarah dan berkesinambungan.

Peran Guru sebagai pendidik berkewajiban untuk meningkatkan hasil belajar siswanya dengan cara menciptakan kegiatan belajar yang mampu membangun kemampuan siswa untuk memahami pelajaran sehingga tercapai hasil yang optimal untuk mencapai tujuan pendidikan. Efektif tidaknya pendidik mengajar akan tergantung pada bagaimana pendidik mampu melaksanakan aktivitas mengajar secara baik. Oleh karena itu guru atau pendidik perlu memperkaya pemahamanya mengenai model pembelajaran. Model pembelajaran dirancang untuk membelajaran peserta didik dan memudahkan bagi guru menggunakan strategi, metode pengajaran yang sesuai dengan mata pelajaran yang menjadi tanggung jawab pendidik. Model pembelajaran yang sesuai dengan kebutuhan materi pelajaran akan menciptakan proses pembelajaran yang berkualitas, sehingga tercapai kompetensi yang telah ditentukan dan membantu guru meningkatkan kemampuannya untuk lebih mengenal potensi peserta didik dan mampu medesain model pembelajaran yang menjadikan peserta didik belajar.

Peserta didik atau siswa terlibat aktif dalam proses pembelajaran ketika guru menerapkan model pembelajaran inovatif, sehingga siswa dapat berpikir kritis, kreatif terhadap proses pembelajaran, akan memahami dan menemukan hal-hal baru untuk menambah pengetahuan. Peserta didik akan belajar dengan baik jika apa yang dipelajarinya terkait dengan apa yang diketahui atau peristiwa yang akan terjadi disekelilingnya. Pembelajaran menekankan keaktifan siswa yaitu menggunakan daya pikir yang tinggi, transfer ilmu pengetahuan, mengumpulkan dan menganalisa data dan memecahkan masalah tertentu, baik secara individu maupun kelompok.

Pelajaran IPS pada kenyataannya beranggapan memuat materi sosial sehingga oleh banyak pihak termasuk sebagaian guru, diasosiasikan sebagai materi yang bersifat hafalan. Pendapat tersebut sudah tentu keliru karena IPS adalah pelajaran yang harus dimaknai. Salah satu kendala dalam proses pembelajaran IPS di sekolah tersebut adalah kesulitan siswa memahami materi pelajaran IPS dengan menggunakan metode ceramah guru atau penerapan pembelajaran yang kurang efektif. Guru kurang maksimal memanfaatkan media dalam mengajar. Siswa kurang dilibatkan dalam berpartisipasi dengan 
lingkungannya, motivasi siswa dalam mengikuti mata pelajaran Ilmu Pengetahuan Sosial juga masih kurang.

Akibat dari permasalahan di atas hasil belajar kelas VI tahun pelajaran 2019/2020 yang diperoleh siswa kurang maksimal, atau masih dibawah Kriteria Ketuntasan Maksimal (KKM) yang telah diterapkan di sekolah, dari informasi yang diberikan guru kelas. Hal ini dapat dilihat dari tabel berikut :

Tabel 1.1 Data Nilai Mata Pelajaran IPS SD Negeri 040451

\begin{tabular}{|c|c|c|c|c|c|}
\hline \multirow{2}{*}{$\begin{array}{c}\text { Tahun } \\
\text { Pelajaran }\end{array}$} & \multirow{2}{*}{ KKM } & \multirow{2}{*}{$\begin{array}{c}\text { Jumlah } \\
\text { Siswa }\end{array}$} & \multicolumn{2}{|c|}{ Jumlah siswa } & \multirow{2}{*}{$\begin{array}{c}\text { Nilai rata- } \\
\text { rata siswa }\end{array}$} \\
\cline { 4 - 5 } & & & Tuntas & Tidak Tuntas & \\
\hline $2018 / 2019$ & 70 & 31 & $20(64 \%)$ & $11(36 \%)$ & 65 \\
\hline
\end{tabular}

( Sumber : Data SD Negeri 040462)

Untuk mengatasi hasil belajar kurang maksimal tersebut guru perlu menggunakan model pembelajaran yang efektif dalam pembelajaran. Salah satunya yaitu dengan menggunakan model pembelajaran Tipe Jigsaw. Model pembelajaran Tipe Jigsaw dapat meningkatkan tanggung jawab siswa terhadap pelajarannya dan pembelajaran orang lain, secara mandiri siswa dituntut memiliki saling ketergantungan yang positif (saling memberi tahu) terhadap teman sekelompoknya...

Berdasarkan uraian diatas penulis memilih judul penelitian "Implementasi Model Kooperatif Tipe Jigsaw dalam Meningkatkan Hasil Belajar Siswa Tema Globalisasi Sub Tema Masyarakat Asean Bebas Narkoba Kelas VI SD 040462 Kabanjahe Tahun Pelajaran 2019/2020

Berdasarkan batasan masalah di atas, maka rumusan masalah dalam penelitian ini adalah sebagai berikut :
1. Bagaimana
Pelaksanaan
Pembelajaran dengan
Mengimplementsikan Model
Pembelajaran Tipe Jigsaw Pada
Tema Globalisasi Sub Tema Masyarakat Asean Bebas Narkoba Kelas VI SD Negeri 040462

Kabanjahe Tahun Pelajaran 2019/2020

2. Bagaimana Ketuntasan Hasil Belajar Siswa dengan Mengimplementasikan Model Pembelajaran Tipe Jigsaw Pada Tema Globalisasi Sub Tema Masyarakat Asean Bebas Narkoba Kelas VI SD Negeri 040462 Kabanjahe Tahun Pelajaran 2019/2020

3. Apakah Hasil Belajar Siswa Meningkat dengan Mengimplementasikan Model Pembelajaran Tipe Jigsaw Pada Tema Globalisasi Sub Tema Masyarakat Asean Bebas Narkoba Kelas VI SD Negeri 040462 Kabanjahe Tahun Pelajaran 2019/2020

\section{Tujuan Penelitian}

Berdasarkan batasan masalah di atas, yang menjadi tujuan penelitian ini adalah sebagai berikut :

1. Untuk Mengetahui Bagaimana Pelaksanaan Pembelajaran dengan. Mengimplementasikan Model Pembelajaran Tipe Jigsaw Pada Tema Globalisasi Sub Tema Masyarakat Asean Bebas Narkoba Kelas VI SD Negeri 040462 


Kabanjahe Tahun Pelajaran
2019/2020

2. Untuk Mengetahui Ketuntasan Hasil Belajar Siswa dengan Mengimplementasikan Model Pembelajaran Tipe Jigsaw Pada Tema Globalisasi Sub Tema Masyarakat Asean Bebas Narkoba Kelas VI SD Negeri 040462 Kabanjahe Tahun Pelajaran 2019/2020

3. Untuk Mengetahui Peningkatan Hasil Belajar dengan Mengimplementasikan Model Pembelajaran Tipe Jigsaw Pada Tema Globalisasi Sub Tema Masyarakat Asean Bebas Narkoba Kelas VI SD Negeri 040462 Kabanjahe Tahun Pelajaran 2019/2020

\section{A. KAJIAN TEORITIS}

\section{Pengertian Pembelajaran}

Pembelajaran

membelajarkan siswa dengan menggunakan asas pendidikan maupun teori belajar, sehingga menjadi penentu utama keberhasilan pendidikan. Pembelajaran merupakan proses komunikasi dua arah, mengajar dilakukan oleh pihak guru sebagai pendidik, sedangkan belajar dilakukan oleh peserta didik atau murid. Menurut Asep Jihad (2013: 11) "Pembelajaran merupakan suatu proses yang terdiri dari kombinasi dua aspek, yaitu belajar tertuju kepada apa yang harus dilakukan oleh siswa, mengajar berorientasi pada apa yang harus dilakukan oleh guru sebagai pemberi pelajaran".

Menurut Winkel dalam Asis Saefuddin dan Ika Berdiati (2015:9) "Pembelajaran merupakan seperangkat tindakan yang dirancang untuk mendukung proses belajar siswa, dengan memperhitungkan kejadian-kejadian ekstrim yang berlangsung dialami siswa.
Selanjutnya menurut Undang-undang Sisdiknas No. 20 Tahun 2003 "Pembelajaran diartikan sebagai proses interaksi peserta didik dengan pendidik dan sumber belajar pada suatu lingkungan belajar".

Menurut Hausstatter dan Nordkvelle dalam Huda Miftahul (2014:5) "Pembelajaran adalah merefleksikan pengetahuan konseptual yang digunakan secara luas dan memiliki banyak makna yang berbeda-beda".

Berdasarkan pengertian di atas, dapat diartikan bahwa pembelajaran merupakan upaya pendidik untuk memberikan kesempatan kepada siswa untuk berpikir agar mengenal dan memahami sesuatu yang dipelajari.

\section{Pengertian Hasil Belajar}

Hasil belajar merupakan salah satu indikator yang digunakan oleh guru untuk mengukur kemampuan siswa dalam proses belajar mengajar baik dalam aspek kognitif, aspek afektif, aspek psikomotorik. Selain itu hasil belajar juga dapat menggambarkan seberapa besar tingkat pencapaian siswa akan materi pembelajaran yang diajarkan dalam proses belajar mengajar. Hasil belajar akan tercermin dari kepribadian siswa yang berupa perubahan tingkah laku, yang berwujud setelah mengalami proses pembelajaran.

Menurut Nawawi dalam Ahmad Susanto (2013:5) menyatakan "Hasil belajar adalah tingkat keberhasilan siswa dalam mempelajari materi pelajaran di sekolah yang dinyatakan dalam skor yang diperoleh dari hasil tes mengenai sejumlah materi pelajaran tertentu".

\section{Faktor- faktor yang Mempengaruhi Hasil Belajar}

Menurut Slameto (2016:54), faktorfaktor yang mempengaruhi belajar dapat digolongkan menjadi dua golongan, yaitu faktor intern dan 
faktor ekstern. Faktor intern adalah faktor yang ada dalam diri individu yang sedang belajar, sedangkan faktor ekstern adalah faktor yang ada di luar individu.

a. Faktor-faktor Intern

Faktor intern terbagi menjadi tiga faktor yaitu faktor jasmaniah, faktor psikologis, dan faktor kelelahan. Faktor jasmaniah dapat terbagi menjadi dua yaitu faktor kesehatan dan cacat tubuh. Faktor psikologis tergolong menjadi tujuh yaitu intelegensi, perhatian, minat, bakat, motif, kematangan, dan kesiapan. Faktor kelelahan pada seseorang walaupun sulit untuk dipisahkan tetapi dapat dibedakan menjadi dua macam yaitu kelelahan jasmani dan kelelahan rohani (bersifat psikis).

b. Faktor-faktor ekstern

Faktor ekstern dapat dikelompokkan menjadi tiga faktor yaitu faktor keluarga, faktor sekolah, dan faktor masyarakat. Pada faktor keluarga, siswa yang belajar akan menerima pengaruh dari keluarga berupa: cara orang tua mendidik, relasi antara anggota keluarga, suasana rumah tangga dan keadaan ekonomi keluarga. Faktor sekolah yang mempengaruhi belajar ini mencakup metode mengajar, kurikulum, relasi guru dengan siswa, relasi siswa dengan siswa, disiplin sekolah, pelajaran dan waktu sekolah, standar pelajaran, keadaan gedung, metode belajar dan tugas rumah. Faktor masyarakat juga mempengaruhi belajar siswa yaitu kegiatan siswa dalam masyarakat, mass media, teman bergaul dan bentuk kehidupan masyarakat.

4. Pengertian Model Pembelajaran Tipe Jigsaw

Martinis
menyatakan bahwa kooperatif tipe jigsaw merupakan struktur yang setiap anggota kelompoknya bertanggungjawab untuk mempelajari anggota-anggota lain tentang salah satu bagian materi". Dalam penerapan jigsaw, setiap anggota kelompok diberi materi yang harus dipelajari oleh seluruh kelompok dan menjadi pakar dibagiannya.Peserta didik harus saling mengajar jadi kontribusi setiap orang penting. Model tipe Jigsaw didesain untuk meningkatkan rasa tanggungjawab, siswa secara mandiri dituntut memiliki saling kebergantungan positif (saling memberitahu) terhadap teman sekelompoknya.

5. Kelebihan dan Kekurangan Model Pembelajaran Tipe Jigsaw

a. Kelebihan Model Pembelajaran Tipe Jigsaw

Kelebihan Model Tipe Jigsawadalah melibatkan seluruh siswa dalam belajar dan sekaligus mengajar kepada orang lain. Hisam dalam Istarani (2012:28)mengemukakan kelebihan Tipe Jigsaw diantaranya yaitu:

1) Ketika kita ingin menekankan pentingnya belajar kolektif.

2) Ketika kita ingin siswa menukar ide dan melihat bahwa mereka dapat belajar dari yang satu dengan yang lainnya.

3) Ketika kita ingin meningkatkan ketrampilan berkomunikasi siswa.

4) Ketika kita ingin mendorong dan mengembangkan kerjsama siswa 
5) Ketika ingin meningkatkan pemahaman siswa secara mendalam .

.b. Kekurangan Model Pembelajaran Tipe Jigsaw

Kelemahan dari model ini menurut Hisam ( 2012:28) adalah sebagai berikut :

1. Beberapa siswa mungkin pada awalnya segan mengeluarkan ide, takut dinilai temannya dalam grup.

2. Tidak semua siswa secara otomatis memahami dan menerima filosofi jigsaw. Guru banyak tersita waktu mensosialisasikan siswa belajar dengan cara ini.

3. Sulit membentuk kelompok yang sulit bekerjasama dengan secara harminis. Penilaian terhadap murid sebagai individu menjadi sulit karena tersembunyi dalam kelompok.

\section{Langkah-langkah Model}

\section{Pembelajaran Problem Solving}

Menurut Aris Shoimin langkah-langkah model pembelajaran Problem Solving ( 2014:137) adalah sebagai berikut:

a. Masalah sudah ada dan materi diberikan.

b. Siswa diberi masalah sebagai pemecahan/diskusi, kerja kelompok.

c. Masalah tidak dicari.

d. Siswa ditugaskan untuk mengevaluasi.

e. Siswa memberikan kesimpulan dari jawaban yang diberikan sebagai hasil akhir. f. Penerapan pemecahan terhadap masalah yang dihadapi sekaligus

$\begin{array}{lr}\text { berlaku } & \text { sebagai } \\ \text { pengujian kebenaran } \\ \text { pemecahan tersebut } \\ \text { untuk dapat sampai } \\ \text { kepada kesimpulan.. }\end{array}$

\section{Pengertian Penelitian Tindakan} Kelas (PTK)

Penelitian Tindakan Kelas (PTK) adalah penelitian yang dilakukan oleh guru di kelasnya sendiri melalui refleksi diri dengan tujuan untuk memperbaiki kinerjanya sehingga hasil belajar siswa meningkat. Bahri (dalam Fita, 2017:23) menyatakan bahwa "PTK merupakan sebuah kegiatan yang dilaksanakan untuk mengamati kejadian-kejadian dalam kelas untuk memperbaiki praktik dalam pembelajaran agar lebih berkualitas dalam proses sehingga hasil belajar pun menjadi lebih baik".

\section{Manfaat Penelitian Tindakan Kelas}

Penelitian Tindakan Kelas merupakan salah satu cara yang strategis bagi pendidik untuk meningkatkan atau memperbaiki layanan pendidikan dalam kenteks pembelajaran di kelas, dan sangat bermanfaat bagi pelaksanaan pembelajaran.

Menurut Rustam dan Mundilarto (2017:37) manfaat PTK adalah sebagai berikut

a) Manfaat untuk guru

1) Membantu guru memperbaiki mutu pembelajaran

2) Meningkatkan profesionalitas guru

3) Meningkatkan rasa percaya diri guru.

b) Manfaat untuk siswa.

1) Peningkatan dan perbaikan kinerja siswa di sekolah

2) Peningkatan dan perbaikan kualitas dalam penerapan 
kurikulum dan pengembangan kompetensi siswa di sekolah

3) Memupuk dan meningkatkan keterlibatan, kegairahan, ketertarikan, kenyamanan dan kesenangan dalam diri siswa untuk mengikuti proses pembelajaran di kelas. Disamping itu, hasil belajar siswa pun dapat meningkat.

c) Manfaat untuk sekolah.

1) Meningkatkan mutu isi, masukan, proses, dan hasil pendidikan dan pembelajaran di sekolah

2) Membantu guru dan tenaga kependidikan lainnya dalam mengatasi masalah pembelajaran dan pendidikan di dalam dan luar kelas.

3) Meningkatkan sikap profesional pendidik dan tenaga kependidikan.

d) Manfaat untuk perkembangan teori pendidikan.

Penelitian Tindakan Kelas (PTK) dapat menjembatani antara teori dan

praktik.

8. Pelaksanaan Pembelajaran dan Ketuntasan Belajar

Pembelajaran dikatakan efektif jika pelaksanaan pembelajaran berlangsung baik dan pembelajaran dikatakan berhasil jika tes yang diberikan guru dikerjakan siswa dengan baik. Hal ini terlihat hubungan timbal balik yang terjadi antara guru dan siswa pada proses pembelajaran dan tingginya persentase siswa yang mendapat nilai baik dalam model pembelajaran Problem Solving.

Kriteria penilaian dalam pelaksanaan pembelajaran aktifitas guru Piet A. Sahertian(2013:61) sebagai berikut
Baik Sekali

$$
\mathrm{A}=81-100 \%
$$

Baik $\quad B=61-80 \%$

Cukup

$$
\mathrm{B}=61-80 \%
$$

$\mathrm{D}=21-40 \%$

Kurang

$$
\mathrm{C}=41-60 \%
$$$$
\mathrm{D}=21-40 \%
$$

Sangat Kurang

Adapun kriteria penilaian dalam pelaksanaan pembelajaran siswa menurut Asep Jihad dan Abdul Haris (2013:131) sebagai berikut :

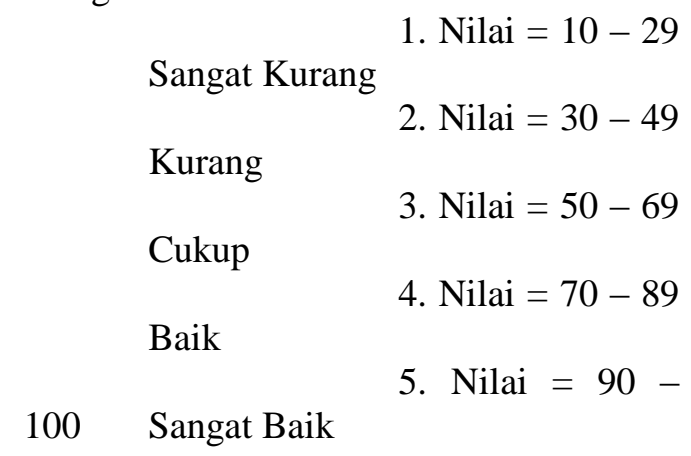

Ketuntasan Belajar dituangkan Depdikbud dalam Trianto (2014:241) menyatakan "Setiap siswa dikatakan tuntas belajarnya (ketuntasan individu) jika proporsi jawaban benar siswa $\geq 65 \%$ dan suatu kelas dikatakan tuntas belajarnya (ketuntasan klasikal) jika dalam kelas tersebut terdapat $\geq 85 \%$ siswa yang telah tuntas belajarnya.

\section{B. METODOLOGI PENELITIAN}

\section{Desain Penelitian}

Sesuai dengan jenis penelitian ini, yaitu penelitian tindakan kelas maka penelitian ini memiliki tahapan yang berupa siklus. Rancangan masing-masing siklus terdiri dari empat tahap yaitu: perencanaan, pelaksanaan, pengamatan, dan refleksi (Arikunto, 2015: 42). 




Gambar 3.1: Model PTK Suharsimi Arikunto

Teknik Pengumpul Data

a. Lembar observasi guru dan siswa

Pengamatan atau observasi adalah teknik yang dilakukan dengan cara melakukan pengamatan secara teliti serta pengamatan secara sistematis meliputi aktivitas kinerja guru dan keaktifan siswa dalam pembelajaran IPS menerapkan
Model problem solving, tujuannya mengetahui kesesuaian tindakan dengan rencana yang telah disusun dan guna mengetahui sejauhmana pelaksaaan tindakan dapat menghasilkan perubahan yang sesuai dengan yang dikehendaki.

b. Tes 
Tes adalah suatu alat atau proses yang sistematis dan objektif untuk memperoleh data-data atau keterangan yang diinginkan seseorang, dengan cara yang boleh dikatakan tepat dan cepat. Tes yang diberikan kepada siswa yaitu tes tertulis dalam bentuk essay test

\section{Teknik Analisis Data}

Untuk mengetahui keefektifan suatu model dalam kegiatan pembelajaran, perlu dilakukan analisis data. Untuk menganalis data yang diperoleh dari hasil test dapat digunakan rumus:

Untuk menganalisis hasil observasi aktivitas guru dan siswa ditentukan dengan rumus:

\section{a. Penilaian Aktifitas Guru}

$H P \frac{\text { Jumlah hasil observasi }}{\text { Jumlah butir pengamatan }}=$

( Piet A. Sahertien 2010:61)

\section{b. Penilaian Aktivitas siswa}

$$
\begin{array}{r}
\text { nilai siswa }=\frac{\text { skor perolehan }}{\text { skor maksimum }} \times 100 \\
\text { (Jihad dan }
\end{array}
$$

$$
\text { Haris,2012:131) }
$$

\section{c. Ketuntasan Hasil belajar siswa \\ Ketuntasan Individu}

Berdasarkan teori yang telah dibuat, maka untuk mengetahui persentase kemampuan siswa secara individu digunakan rumus sebagai berikut:',

$\mathrm{KB}=\frac{\mathrm{T}}{\mathrm{Tt}} \times 100 \%$

(Trianto,2011:241)

Keterangan :
KB : Ketuntasan Belajar

$\mathrm{T}$ : Jumlah skor yang diperoleh siswa

Tt : Skor total

Ketuntasan Klasikal

Persentase ketuntasan belajar siswa secara klasikal dirumuskan sebagai berikut:

$p=\frac{\sum \text { siswa yang tuntas belajar }}{\sum \text { siswa }} \times 100 \%$

(Zainal

Aqib,2010:41)

d. Peningkatan Hasil Belajar Siswa

Nilai rata-rata

Untuk melihat nilai rata-rata yang diperoleh siswa kita dapat menggunakan rumus:

$$
\bar{x}=\frac{\sum f i . x i}{\sum f i}
$$

2012:70)

(Sudjana,

Keterangan:

$\bar{x}=$ Nilai Rata - Rata

$\sum$ fi. $x i=$ Jumlah Semua Nilai Siswa

$\sum f i=$ Jumlah Siswa

Persentase Peningkatan Hasil

Belajar Siswa

Untuk mencari apakah hasil belajar meningkat atau tidak dapat digunakan rumus sebagai berikut.

$$
\mathrm{P}=
$$

$$
\frac{\bar{x} \text { Siklus II- } \bar{x} \text { Siklus I }}{\bar{x} \text { Siklus I }} \times 100 \%
$$

\section{HASIL DAN PEMBAHASAN}

Dari hasil penelitian yang dilaksanakan dengan

Mengimplementsikan Model Pembelajaran Tipe Jigsaw Pada Tema Globalisasi Sub Tema Masyarakat Asean Bebas Narkoba Kelas VI SD Negeri 040462 Kabanjahe Tahun Pelajaran 2019/2020 


\section{Data temuan dan analisa}

Berdasarkan hasil observasi pada siklus I dari aktivitas guru diperoleh $60 \%$ kreteria cukup dan aktivitas siswa diperoleh nilai 66 kreteria cukup. Ketuntasan Hasil Belajar Siswa 68\%(21 siswa) dan sebanyak $22 \%$ (10 siswa) yang tidak tuntas dengan Mengimplementsikan Model Pembelajaran Tipe Jigsaw Pada Tema Globalisasi Sub Tema Masyarakat Asean Bebas Narkoba Kelas VI SD Negeri 040462 Kabanjahe Tahun Pelajaran 2019/2020. Dalam hal ini secara klasikal hasil belajar siswa pada siklus I belum tuntas karena belum mencapai $\geq 85 \%$ siswa yang tuntas belajarnya

\section{Refleksi Siklus I}

Berdasarkan analisa data siklus I pelaksanaan pembelajaran belum mencapai kreteria baik dan ketuntasan belajar secara klasikal belum mencapai $85 \%$, maka , perlu dilanjutkan kembali penelitian tindakan kelas pada siklus II dengan merefleksi aspek aspek pelaksanaan aktivitas guru dan siswa yang belum mencapai kreteria baik. sebagai berikut.

a. Aktivitas Guru

1) Penguasaan kelas, tindakan pada siklus II dengan mengatakan kepada siswa hai hai halo dan tepuk diam kemudian siswa menjawab halo halo hai dan melakukan tepuk diam, dengan demikian penguasaan kelas dapat terjaga.

2) Penggunaan model pembelajaran Tipe Jigsaw pada proses pembelajaran, tindakan pada siklus II dengan menjelaskan langkah langkah model pembelajaran Tipe
Jigsaw sebelum masuk ke inti pembelajaran.

b. Aktivitas Siswa

1) Keaktifan siswa menjelaskan materi kepada kelompok asal, tindakan pada siklus II adalah melibatkan seluruh siswa untuk aktif dan memberi hadiah permen bagi yang aktif bertanya.

2) Ketenangan siswa pada saat belajar, tindakan pada siklus II dengan mengarahkan siswa untuk mendiskusikan dampak globalisasi mengawasi jalannya diskusi tersebut.

Berdasarkan data Hasil penelitian siklus II pelaksanaan aktivitas guru adalah $80 \%$ kreteria baik, aktivitas siswa diperoleh nilai 85 kreteria baik Dengan demikian pelaksanaan pembelajaran aktivitas guru dan siswa sudah berkriteria baik.

Ketuntasan hasil belajar siswa pada siklus II yaitu terdapat siswa yang tuntas sebanyak 28 (90\%) dan yang tidak tuntas sebanyak 3 siswa (9\%) dengan Mengimplementsikan Model Pembelajaran Tipe Jigsaw Pada Tema Globalisasi Sub Tema Masyarakat Asean Bebas Narkoba Kelas VI SD Negeri 040462 Kabanjahe Tahun Pelajaran 2019/2020. Dalam hal ini secara klasikal hasil belajar siswa pada siklus II sudah tuntas karena telah mencapai $\geq 85 \%$ siswa tuntas belajarnya.Peningktan pesentase hasil belajar adalah $10 \%$

Dengan demikian hasil belajar siswa dengan Mengimplementsikan Model Pembelajaran Tipe Jigsaw Pada Tema Globalisasi Sub Tema Masyarakat Asean Bebas Narkoba Kelas VI SD Negeri 040462 
Kabanjahe Tahun Pelajaran 2019/2020 meningkat dan tuntas secara klasikal.

Peningkatan Hasil Belajar Siswa berdasarkan hasil tes siswa pada siklus I dan siklus II sebagai berikut:

Tabel 3. Nilai Rata-rata Hasil Belajar Siswa

\begin{tabular}{|l|l|l|}
\hline Tes & $\begin{array}{l}\text { Rata- } \\
\text { rata }\end{array}$ & Peningkatan \\
\hline Siklus I & 70 & $5 \%$ \\
\hline Siklus II & 75 & \\
\hline
\end{tabular}

\section{Simpulan}

Berdasarkan hasil pembahasan pada Bab IV dapat ditarik kesimpulan bahwa :

1. Pelaksanaan pembelajaran dengan Mengimplementasikan Model Pembelajaran Tipe Jigsaw Pada Tema Globalisasi Sub Tema Masyarakat Asean Bebas Narkoba Kelas VI SD Negeri 040462 Kabanjahe Tahun Pelajaran 2019/2020 kreteria baik

2. Hasil belajar siswa tuntas secara klasikal. dengan Mengimplementasikan Model Pembelajaran Tipe Jigsaw Pada Tema Globalisasi Sub Tema Masyarakat Asean Bebas Narkoba Kelas VI SD Negeri 040462 Kabanjahe Tahun Pelajaran 2019/2

3. Hasil belajar siswa meningkat dengan Mengimplementasikan Model Pembelajaran Tipe Jigsaw Pada Tema Globalisasi Sub Tema Masyarakat Asean Bebas Narkoba Kelas VI SD Negeri 040462
Kabanjahe Tahun Pelajaran 2019/2020

\section{DAFTAR PUSTAKA}

Aqib Zainal, 2016. Penelitian Tindakan Kelas. Bandung : CV Yrama Widya.

Arikunto, Suharsimi dkk.2015. Penelitian Tindakan Kelas. Jakarta: Bumi Aksara

Ainurrahman, 2012. Belajar dan Pembelajaran. Bandung : Alfabeta

Dimyati dan Mudjiono, 2016 .Belajar dan Pembelajaran. Jakarta: Rineka Cipta

Fita Nur Arifah, 2017. Penelitian Tindakan Kelas dan Karya Ilmiah Untuk Guru,

$$
\text { Araska }
$$

Huda, Miftahul. 2014. Model-Model Pengajaran dan pembelajaran. Yogyakarta:

$$
\text { Pustaka Pelajar }
$$

Jihad, Asep. 2012. Evaluasi Pembelajaran. Yogyakarta: Multi Pressindo

Purwanto. 2011. Evaluasi Hasil Belajar. Yogyakarta: Pustaka Pelajar Sahaertian.Piet.2013 Konsep Dasar dan Teknik Supervisi Pendidikan dalam

Pengembangan Sumber daya Manusia. Jakarta: Rineka Cipta

Sagla, Syaiful. (2013). Konsep dan Makna Pembelajaran, Bandung: CV Alfabeta

Shoimin, Aris. 2014. 68 Model Pembelajaran Inovatif. Yogyakarta: Ar-Ruzz Media 
Slameto, 2016. Belajar dan Faktor yang mempengaruhinya. Jakarta: Rineka Cipta

Sujana, 2012. Metode Statistik. Bandung: Tarsito

Sukardi, 2013. Metode Penelitian Tindakan Kelas. Jakarta: PT Aksara
Trianto. 2011. Mendesain Model pembelajaran Inovativ progresif, Jakarta: Prenada

Media Group. Undang -Undang RI No 14 Tahun 2005, 2006, Guru dan Dosen. Jakarta: Ciputat 